\title{
Occurrence of Ehrlichia canis and Anaplasma platys in household dogs from northern Parana
}

\author{
Ocorrência de Ehrlichia canis e Anaplasma platys em cães domiciliados da região norte do Paraná \\ Gislaine Cristina Ferreira da Silva ${ }^{1}$; Aline do Nascimento Benitez ${ }^{1}$; Aline Girotto ${ }^{1}$; Alessandra Taroda ${ }^{1}$; \\ Marilda Carlos Vidotto ${ }^{2}$; João Luis Garcia ${ }^{2}$; Julio Cesar de Freitas²; Selwyn Arlington Headley ${ }^{3}$; Odilon Vidotto ${ }^{2 *}$ \\ ${ }^{1}$ Programa de Pós-graduação em Ciência Animal, Universidade Estadual de Londrina - UEL, Londrina, PR, Brasil \\ ${ }^{2}$ Departamento de Medicina Veterinária Preventiva, Universidade Estadual de Londrina - UEL, Londrina, PR, Brasil \\ ${ }^{3}$ Mestrado em Ruminantes, Universidade Norte do Paraná - UNOPAR, Londrina, PR, Brasil
}

Received March 25, 2012

Accepted October 10, 2012

\begin{abstract}
Canine monocytic ehrlichiosis caused primarily by Ehrlichia canis and canine thrombocytic anaplasmosis induced by Anaplasma platys are important emerging zoonotic tick-borne diseases of dogs. There is evidence that these pathogens can also affect humans. This study evaluated the presence of $E$. canis and $A$. platys in blood samples collected from 256 domiciled dogs in the municipality of Jataizinho, located in north region of the State of Parana, Brazil, by PCR assay. The occurrence of $E$. canis and $A$. platys was $16.4 \%$ (42/256) and $19.4 \%$ (49/256), respectively; while $5.47 \%$ (14/256) of the dogs evaluated were co-infected by these two organisms. The presence of E. canis and A. platys was not significantly associated with the variables evaluated (sex, age, outdoor access, and presence of ticks during blood collection). Infection of dogs by E. canis was associated with anemia and thrombocytopenia, while infection induced by A. platys was related only to thrombocytopenia. Canine monocytic ehrlichiosis and canine thrombocytic anaplasmosis should be included in the differential diagnoses when these hematological alterations are observed during routine laboratory evaluation of dogs.
\end{abstract}

Keywords: Canine monocytic ehrlichiosis, canine thrombocytic anaplasmosis, PCR, anemia, thrombocytopenia.

\section{Resumo}

Erliquiose monocítica canina, causada principalmente por Ehrlichia canis, e anaplasmose trombocítica canina, devida a infecçấo com Anaplasma platys, são importantes doenças transmitidas por carrapatos que acometem os cães, com evidências que podem também acometer o homem. O presente estudo avaliou a ocorrência desses agentes em amostras de sangue de 256 cáes domiciliados na cidade de Jataizinho, na região Norte do Paraná, Brasil, utilizando a técnica da Reação em Cadeia da Polimerase (PCR). A ocorrência de E. canis e A. platys foi de 16,4\% (42/256) e 19,4\% (49/256), respectivamente, com 5,47\% (14/256) dos animais apresentando coinfecção. Não foi observada associação significativa com as variáveis sexo, idade, acesso à rua e presença de carrapatos no momento da coleta de sangue. A infecção por $E$. canis teve relaçáo com anemia e com trombocitopenia, enquanto a infecçáo por $A$. platys apresentou relaçáo apenas com trombocitopenia. Com base nos resultados obtidos, reforçou-se a necessidade de que erliquiose e anaplasmose canina devem estar entre os diagnósticos diferenciais, quando da detecção de anemia e trombocitopenia em exames laboratoriais.

Palavras-chave: Erliquiose monocítica canina, anaplasmose trombocítica canina, PCR, anemia, trombocitopenia.

\section{Introduction}

Canine monocytic ehrlichiosis (CME) and canine thrombocytic anaplasmosis (CTA) are infectious diseases caused by gram-negative bacteria of the Order Rickettsiales, family Anaplasmataceae, genera Ehrlichia and Anaplasma (DUMLER et al., 2001). Ehrlichia canis

${ }^{*}$ Corresponding author: Odilon Vidotto

Departamento de Medicina Veterinária Preventiva, Centro de Ciências Agrárias, Rod. Celso Garcia Cid, Pr 445, Km 380, CP 6001,

CEP 86051-980, Londrina, PR, Brasil

e-mail: vidotto@uel.br and Anaplasma platys are obligatorily intracellular organisms organized in clusters, called morulae, and frequently observed in leukocytes and platelets, respectively, with the possibility of concomitant infections (McBRIDE et al., 1996; COHN, 2003; SUKSAWAT et al., 2001a). These infectious diseases are of great importance for small animal clinics and public health, since they are increasingly prevalent in dogs and because there is evidence that these pathogens can also affect humans (DAGNONE et al., 2001; TAMÍ; TAMÍ-MAURY, 2004; NEER; HARRUS, 2006). 
The transmission of E. canis occurs primarily through the bite of the tick, Rhipicephalus sanguineus, and this tick might be associated with the transmission of $A$. platys to dogs (INOKUMA et al., 2000; SUKSAWAT et al., 2001b). Since there is a common vector for both diseases, coinfections in animals are frequent (KORDICK et al., 1999; YABSLEY et al., 2008; DAGNONE et al., 2009).

Routine diagnoses of CME and CTA are based on characteristic clinical and hematological findings. The identification of hemoparasites in blood smears is the most widely used technique in clinical practice to characterize morulae in leukocytes and platelets, but this method has low diagnostic sensitivity and specificity and must be supplemented with the use of molecular techniques, such as PCR (NAKAGHI et al., 2008; DAGNONE et al., 2009; RAMOS et al., 2010).

Existing data of CME and CTA within the region of Londrina, north region of the State of Parana, is restricted to hospital cases (DAGNONE et al., 2003; TRAPP et al., 2006); no study evaluating the occurrence of these diseases in household dogs has been found. This study evaluated the occurrence of E. canis and A. platys in a population of apparently healthy household dogs within the region of Londrina, associating the presence of these agents with possible risk factors and hematological alterations.

\section{Materials and Methods}

\section{Animal, samples, and study area}

Blood samples with EDTA from 256 household dogs were collected from July to August 2010 in the municipality of Jataizinho, located in the north region of the State of Parana, Brazil. These animals, whose owners agreed to participate in this study, were gathered from 124 residences. The number of dogs selected was determined by Epi 6.0 with an expected prevalence of 50\%, 5\% of precision, and $95 \%$ of confidence level.

Part of each sample was kept frozen at $-20{ }^{\circ} \mathrm{C}$ until DNA extraction, and the remainder was used for hematological analysis. Blood sampling was approved by the Ethics Committee for Animal Experiments (\# 34/2011) of the Universidade Estadual de Londrina, Parana state, Brazil., "Universidade Estadual de Londrina" - UEL.

The city of Jataizinho is sidelined by the Tibagi River; it is close to the Tropic of Capricorn, $352 \mathrm{~m}$ above sea level, located at coordinates $23^{\circ} 15^{\prime} \mathrm{S}$ and $50^{\circ} 58^{\prime} \mathrm{W}$. The climate is humid subtropical with hot summers, classified as Cfa according to the Köppen classification. The average annual temperature in Jataizinho is $21.3^{\circ} \mathrm{C}$, with one rainy season, high temperatures during the spring and summer, being cold and dry during the fall and winter (IAPAR, 2011).

\section{Hematological evaluations}

The blood samples collected from the dogs were centrifuged to determine the packed cell volume (PCV) by the microhematocrit method (THRALL, 2007). Duplicate blood smears were fixed with methanol, dried at room temperature and stained with Giemsa to estimate the number of platelets per slide (SILVA et al., 2007). Animals were considered anemic when PCV was lower than 37\%; they were considered thrombocytopenic when platelet count was smaller than 120,000 .

\section{DNA extraction and PCR}

Genomic DNA was extracted from all blood samples with the use of QIAmp DNA Blood Mini Kit (Qiagen ${ }^{\mathrm{TM}}$, Sao Paulo, Brazil), and used for PCR analyses. Molecular-grade water was extracted to confirm that no cross-contamination between samples occurred during DNA extraction.

The primers (EcavB9of, 5'-CATTATCATTTCAATACGTAACTC-3'; EcavB9or, 5'-TTTTGATTTTCTTCTGACATAGTG-3') were used to amplify 959 base pairs (bp) of the virB9 gene of $E$. canis from genomic DNA (FELEK et al., 2003). The 504 bp fragment of $16 \mathrm{~S}$ rRNA gene of $A$. platys was amplified by using the primers platys $16 \mathrm{~S} \mathrm{~F}$ (5'-AAGTCGAACGGATTTTTGTC-3'), and platys 16S R (5'-CTCTCCCGGACTCTAGTC-3') (GOTSCH et al., 2009). According the PCR protocol were used 20 pmol of each primer, $200 \mu \mathrm{M}$ dNTP, 50 ng of genomic DNA, 1X PCR Platinum buffer, $2 \mathrm{mM} \mathrm{MgCl}_{2}$, and 1.25 U Platinum DNA Polymerase ${ }^{\mathrm{R}}$ (Invitrogen Life Technologies, USA) for a final volume of $25 \mu \mathrm{L}$. The PCR amplification cycle consisted of 35 cycles of denaturation $\left(94^{\circ} \mathrm{C}\right.$ for 1 minute), primer annealing of 1 minute $\left(58^{\circ} \mathrm{C}\right.$ for $E$. canis; $60{ }^{\circ} \mathrm{C}$ for $A$. platys), and a final extension $\left(72^{\circ} \mathrm{C}\right.$ for 7 minutes $)$. The PCR products were separated by electrophoresis in $1.5 \%$ agarose gel stained with SyBr Safe (Invitrogen ${ }^{\mathrm{TM}}$, USA) and visualized under UV light. The 100-pb ladder (Promega, Madison, USA) was used as standard for determining the molecular mass of PCR products. Positive controls consisted of E. canis and A. platys DNA extracted from the blood of dogs that had positive PCR, and which amplicons were confirmed by sequencing as being from those species, utilizing commercial kit BigDye Terminator (Applied Biosystems, CA, USA); ultra-pure water served as negative control.

\section{Statistical analysis}

The following variables were analyzed: (a) occurrence of $E$. canis and $A$. platys regarding gender (male and female) of the affected animals; (b) age of infection (0-1 year; $2-5$ years; older than 5 years); (c) outdoor access (yes or no); (d) presence of ticks during blood collection (yes or no); and, (e) possible hematological alterations (anemia and thrombocytopenia). Possible associations between the evaluated variables and positive reaction to the agents were determined by the Chi-square test. The probability of error was accepted up to $5 \%(\mathrm{p}<0.05)$.

\section{Results and Discussion}

The results from this study have demonstrated that blood-derived DNA samples of $30.08 \%$ (77/256) of the dogs evaluated were positive by PCR assays to at least one infectious agent. However, 
$10.94 \%(28 / 256)$ of these reacted positively only to $E$. canis, $13.67 \%(35 / 256)$ to $A$. platys, while coinfection was observed in $5.4 \%(14 / 256)$ of these dogs. Nevertheless, the total prevalence (only one agent or coinfection) of E. canis and A. platys was $16.4 \%$ (42/256) and 19.14\% (49/256), respectively.

PCR assays successfully amplified the 959 bp of the VirB9 gene of $E$. canis and the $504 \mathrm{bp}$ fragment $16 \mathrm{~S}$ rRNA gene of $A$. platys from blood-derived DNA samples. The sequencing of amplified DNA from both pathogens showed 99\% of identity with known sequences deposited in the GenBank (E. canis - AF546158.1 and A. platys - GQ395385.1). The prevalence level observed in this study was inferior to those of similar investigations of $E$. canis made in several cities in the country. These included $22 \%$ in Londrina, State of Parana, (DAGNONE et al., 2003), 35.6\% in Salvador, State of Bahia (SOUZA et al., 2010), and 57\% in Recife, State of Pernambuco (RAMOS et al., 2010). Higher prevalence levels were observed in several cities in the State of Sao Paulo: Ribeirao Preto, 38.9\% (SANTOS et al., 2009); Jaboticabal [53.3\% (NAKAGHI et al., 2008); 72.5\% (FARIA et al., 2010); and 88\% (DAGNONE et al., 2009)], and Botucatu [30.9\% (BULLA et al., 2004); 40\% (UENO et al., 2009); and 77.7\% (DINIZ et al., 2007)]. Nevertheless, the prevalence level of this study was greater than those described in the city of Rio de Janeiro, State of Rio de Janeiro, 15\%, (MACIEIRA et al., 2005) and two cities in the State of Bahia: Ilheus $(10.7 \%$; $9 / 84)$ and Itabuna $(4.3 \% ; 3 / 69)$ (CARVALHO et al., 2008). It must be emphasized that most of these studies were performed with dogs attended at Veterinary Hospitals, or with clinical manifestations and/or hematological alterations consistent with CME. Alternatively, the animals from this study were apparently healthy and the samples were collected during the winter, when the environmental population of ticks in that region is comparatively reduced relative to the spring and summer. Taken together, these two conditions might have influenced the lower rates of infection by $E$. canis observed in this study compared to those described elsewhere.

When the result (19.4\%) of $A$. platys was compared with similar studies, it was possible to observe that the prevalence level derived from this study was lower than that described in Campo Grande, State of Mato Grosso do Sul, 42\% (DAGNONE et al., 2009), and Recife, State of Pernanbuco, 55\% (RAMOS et al., 2009). However, these results were higher than those observed in Rio de Janeiro, State of Rio de Janeiro, 15.84\% (FERREIRA et al., 2007), Jaboticabal, State of Sao Paulo, 8\% (DAGNONE et al., 2009), and Ribeirao Preto, State of Sao Paulo, 14.9\% (SANTOS et al., 2009). Moreover, prevalence levels of $A$. platys in the USA, Venezuela, Italy, and Grenada varied from $4 \%$ to $55 \%$ (KORDICK et al., 1999; HUANG et al., 2005; DE LA FUENTE et al., 2006; YABSLEY et al., 2008). The variation in the percentage of positive animals observed in different studies might be directly related to the canine population evaluated, the degree of exposure to ticks, and the diagnostic method utilized (SOLANO-GALLEGO et al., 2006).

The occurrence $(5.47 \%)$ of coinfections in dogs caused by $A$. platys and $E$. canis reinforces the hypothesis that these infections are probably transmitted by the same vector; similar results were observed in different geographical regions in Brazil (DANTASTORRES, 2008; DAGNONE et al., 2009; RAMOS et al., 2009; SANTOS et al., 2009). This phenomenon was also described in dogs from Thailand (SUKSAWAT et al., 2001b), Venezuela (SUKSAWAT et al., 2001a; HUANG et al., 2005), and Grenada (YABSLEY et al., 2008).

There was no significant association (Table 1) between infection by $E$. canis and the variables evaluated (gender, age, street access, and presence of ticks at the time of blood sampling). Molecular methods demonstrated similar results for the effects of sex and age relative to infection by E. canis in Cuiaba, State of Mato Grosso (SILVA et al., 2010), and Ilheus and Itabuna, State of Bahia (CARVALHO et al., 2008). This pattern was also observed with serological assessments performed in several Brazilian cities: Cuiaba, State of Mato Grosso (SILVA et al., 2010), Monte Negro, State of Rondonia (AGUIAR et al., 2007), Patos, State of Paraiba (AZEVEDO et al., 2011), and southern cities in the State of Rio Grande do Sul (SAITO et al., 2008). Serological surveys made in the USA (RODGERS et al., 1989), Israel (HARRUS et al., 1997), and Japan (INOKUMA et al., 1999) revealed similar findings.

Table 1. Risk factors associated with Ehrlichia canis in a population of household dogs from Jataizinho, State of Parana, Brazil.

\begin{tabular}{|c|c|c|c|c|c|}
\hline Variables & $N$ & PCR (+) & Prevalence (\%) & $\chi^{2}$ & $p$-value \\
\hline \multicolumn{6}{|l|}{ Gender } \\
\hline Male & 142 & 26 & 18.3 & \multirow{2}{*}{0.472} & \multirow{2}{*}{0.4921} \\
\hline Female & 112 & 16 & 14.28 & & \\
\hline \multicolumn{6}{|l|}{ Age } \\
\hline$<1$ year & 43 & 6 & 13.95 & \multirow{2}{*}{0.6291} & \multirow{2}{*}{0.8897} \\
\hline 1 to 5 years & 148 & 24 & 16.22 & & \\
\hline \multicolumn{6}{|l|}{ Street access } \\
\hline Yes & 143 & 22 & 15.38 & \multirow{2}{*}{0.1067} & \multirow{2}{*}{0.744} \\
\hline No & 113 & 20 & 17.70 & & \\
\hline \multicolumn{6}{|l|}{ Presence of ticks at sampling } \\
\hline Yes & 29 & 5 & 17.24 & 0.01885 & 0.8908 \\
\hline
\end{tabular}

$N$, number of dogs; +, number of dogs positive by PCR. 
Alternatively, previous contact of dogs with ticks increased the risk of development CME (TRAPP et al., 2006).

Nevertheless, a higher prevalence of $E$. canis in adult and aged dogs has been described, and it was related to greater exposition to the vector (WATANABE et al., 2004; RODRIGUEZ-VIVAS et al., 2005; COSTA JUNIOR et al., 2007). Although no relationship was observed between street access and the possibility of infection during this study, dogs from the semi-arid region of the State of Paraiba that had restricted street access were more likely to be infected by $E$. canis due to the greater possibility of contact with infected ticks (AZEVEDO et al., 2011).

Moreira et al. (2003) suggested that dogs exposed to ticks are more likely to present elevated levels of infection by E. canis. The absence of significant difference between exposure to ticks and infection in this study might probably be because all samples were collected during the winter. Differences in climatic conditions were attributed as important factors that influence the population dynamics of ticks (COSTA JUNIOR et al., 2007). This was recently demonstrated in a study realized in the State of Minas Gerais, where dogs residing in a geographical location with ideal annual temperature for the development of ticks were shown to be 4.6 times more likely to be seropositive for $E$. canis, when compared to dogs living in cities where the average annual temperature is lower (COSTA JUNIOR et al., 2007). Currently, the only known natural method of transmission is via contact with infected ticks; hence, it is likely that the dogs that reacted positively to $E$. canis might have had contact with the vector prior to the sampling, and ticks might not have been observed during sample collection.

Significant association was not observed (Table 2) between infections induced by $A$. platys and the evaluated variables (sex, age, street access, and presence of ticks at the time of sampling). Different from studies associated with E. canis, there is little data regarding the risk factors associated with infections induced by A. platys in Brazil (DANTAS-TORRES, 2008).

One of the hematological alterations frequently observed in dogs diagnosed with CME is anemia, which is usually normocytic, normochromic, and nonregenerative, suggesting restricted or no bone marrow response (HARRUS et al., 1997; BULLA et al.; 2004; BORIN et al. 2009; GAUNT et al., 2010). These hematological alterations in this anemic disease are probably caused by the combined or isolated effects of the reactions induced by the monocyte-phagocyte system, cell lysis due to the action of the complement system, and suppression of erythropoiesis in the bone marrow are the mechanisms responsible for the table identified as anemic disease (MOREIRA et al., 2003).

When the number of dogs positive for $E$. canis was evaluated, $28.57 \%$ (12/42) were anemic, while only $13.94 \%$ (29/208) of dogs that were negative by PCR presented anemia (Table 3). Therefore, the proportion of anemic dogs was significantly higher than that of dogs infected with E. canis, suggesting that CME is an important cause of anemia in dogs. Similar findings were described in populations of hospitalized dogs (DAGNONE et al., 2003; NAKAGHI et al., 2008). Alternatively, no positive association

Table 2. Risk factors associated with Ehrlichia canis in a population of household dogs from Jataizinho, State of Parana, Brazil.

\begin{tabular}{|c|c|c|c|c|c|}
\hline Variables & $N$ & $\operatorname{PCR}(+)$ & Prevalence (\%) & $\chi^{2}$ & $p$-value \\
\hline \multicolumn{6}{|l|}{ Gender } \\
\hline Males & 142 & 28 & 19.72 & \multirow{2}{*}{0.001159} & \multirow{2}{*}{0.9728} \\
\hline Females & 112 & 21 & 18.75 & & \\
\hline \multicolumn{6}{|l|}{ Age } \\
\hline$<1$ year & 43 & 8 & 18.6 & \multirow{4}{*}{1.828} & \multirow{4}{*}{0.6088} \\
\hline 1 to 5 years & 148 & 27 & 18.24 & & \\
\hline$>5$ years & 57 & 11 & 19.3 & & \\
\hline Not determined & 8 & 3 & 37.5 & & \\
\hline \multicolumn{6}{|l|}{ Street access } \\
\hline Yes & 143 & 32 & 22.38 & \multirow{2}{*}{0.09337} & \multirow{2}{*}{0.1867} \\
\hline No & 113 & 17 & 15.04 & & \\
\hline \multicolumn{6}{|c|}{ Presence of ticks at sampling } \\
\hline Yes & 29 & 8 & 27.58 & \multirow{2}{*}{0.1643} & \multirow{2}{*}{0.3285} \\
\hline No & 227 & 41 & 18.06 & & \\
\hline
\end{tabular}

$N$, number of dogs; +, number of dogs positive by PCR.

Table 3. Manifestations of anemia and thrombocytopenia relative to Ehrlichia canis within a population of household dogs from Jataizinho, State of Parana, Brazil.

\begin{tabular}{|c|c|c|c|c|}
\hline Clinical manifestation & PCR positive & PCR negative & $\chi^{2}$ & $p$ \\
\hline Anemia & $(n=42)$ & $(n=208)$ & & \\
\hline Yes & $28.57 \%(12)$ & $13.94 \%(29)$ & \multirow{2}{*}{4.44} & \multirow{2}{*}{0.0311} \\
\hline No & $71.43 \%(30)$ & $86.06 \%(179)$ & & \\
\hline Thrombocytopenia & $(n=42)$ & $(n=205)$ & & \\
\hline Yes & $59.52 \%(25)$ & $36.58 \%(75)$ & \multirow{2}{*}{6.69} & \multirow{2}{*}{0.009696} \\
\hline No & $40.47 \%(17)$ & $63.41 \%(130)$ & & \\
\hline
\end{tabular}


Table 4. Manifestations of anemia and thrombocytopenia relative to Anaplasma platys within a population of household dogs from Jataizinho, State of Parana, Brazil.

\begin{tabular}{|c|c|c|c|c|}
\hline Clinical manifestation & PCR positive & PCR negative & $\chi^{2}$ & $p$ \\
\hline Anemia & $(n=49)$ & $(n=201)$ & & \\
\hline Yes & $20.41 \%(10)$ & $15.42 \%(31)$ & \multirow{2}{*}{0.3968} & \multirow{2}{*}{0.5287} \\
\hline No & $79.59 \%(39)$ & $84.57 \%(170)$ & & \\
\hline Thrombocytopenia & $(n=47)$ & $(n=200)$ & & \\
\hline Yes & $61.70 \%(29)$ & $35.5 \%(71)$ & \multirow{2}{*}{9.784} & \multirow{2}{*}{0.001761} \\
\hline No & $38.29 \%(18)$ & $64.5 \%(129)$ & & \\
\hline
\end{tabular}

between anemia and infection by $E$. canis was observed in dogs from the State of Minas Gerais (COSTA JUNIOR et al., 2007), State of Mato Grosso (SOUZA et al., 2010), and Botucatu, State of Sao Paulo (UENO et al., 2009). These hematological differences might be directly related to the phase of infection at the time of sampling (HARRUS et al., 1997; BULLA et al., 2004), or a manifestation of the diverse pathogenicity of the strain (DAGNONE et al., 2003).

Thrombocytopenia, which is also frequently associated with CME, occurred in $59.52 \%$ (25/42) of the dogs evaluated during this study (Table 3), but it was only observed in 36.58\% (75/205) of dogs that were PCR-negative for E. canis. These results showed that a proportionally significant number of dogs infected by this pathogen were thrombocytopenic, indicating that this hematological alteration is an important clinical manifestation of CME. Similar results confirming the association of thrombocytopenia and infection by E. canis in dogs were described in Botucatu, State of Sao Paulo (BULLA et al., 2004) and Rio de Janeiro, State of Rio de Janeiro (MACIEIRA et al., 2005).

Several mechanisms have been proposed to explain the cause of thrombocytopenia in dogs with CME, such as increased consumption of platelets, splenic sequestration, destruction by immune-mediated mechanisms, and associated platelet dysfunction (HARVEY, 2006; GAUNT et al., 2010). However, not all thrombocytopenic dogs from the geographical region where this study was carried out are positive for CME, since it was demonstrated that only $19.7 \%$ (12/61) of hospitalized dogs from this area that were infected by $E$. canis were thrombocytopenic (DAGNONE et al., 2003). This would suggest that CME is not the only cause of thrombocytopenia in dogs from this geographical location. A recent study done in the same geographical location suggested that thrombocytopenia was more associated with canine babesiosis, induced by Babesia vogeli, relative to CME (TRAPP et al., 2006). Additionally, thrombocytopenia is not observed in all dogs experimentally inoculated with E. canis (GAUNT et al., 2010). Further, although this hematological alteration is more frequently observed in cases of CME, thrombocytopenia might also be associated with CTA induced by $A$. platys (SANTOS et al., 2009).

In the present study, no relationship was observed between PCR positivity for $A$. platys and the possibility to develop anemia (Table 4). Similar results were described in an experimental study that did not observe reduction in the packed cell volume of dogs infected with $A$. platys (GAUNT et al., 2010). Most (61.7\%; 29/47) dogs that were PCR-positive for $A$. platys presented thrombocytopenia, while only $35.5 \%(71 / 200)$ of dogs that were PCR-negative were thrombocytopenic. Consequently, the proportion of dogs with thrombocytopenia is significantly higher in those infected with $A$. platys, suggesting that canine anaplasmosis is also an important cause of this hematological alteration. Similar associations were described in a recent experimental study (GAUNT et al., 2010).

Different investigative strategies have been used to associate the prevalence of hemoparasites with hematological alterations, including the identification of the infectious agent in dogs with anemia and/or thrombocytopenia. However, this frequently induces bias selection and undermines prevalence data, since thrombocytopenic dogs are more likely to be positive for CME (DAGNONE et al., 2003), while thrombocytopenia is not always associated with CME in some geographical locations of Brazil (TRAPP et al., 2006). Therefore, it would be worth comparing the prevalence of these infectious agents in dogs with and without the characteristic clinical manifestations of CME and CTA. In this case, if prevalence levels are higher in dogs with clinical manifestations, the data should be interpreted as a consequence of the infectious agent and not as risk factors that might predispose the animal to infection (CARLOS et al., 2011).

Alternatively, it is also possible to evaluate dogs that have reacted positively to one infectious agent by comparing the ratio of anemic and/or thrombocytopenic dogs with dogs having the globular volume and/or platelets scores within reference limits. In this case, if the percentage of anemic and/or thrombocytopenic dogs is greater than that with normal reference values, it is often erroneously concluded that the agent is responsible for these alterations. Moreover, it is also important to evaluate these manifestations within the population of non-reactive dogs. The finding of a ratio that is equal between positive and negative dogs, in this case, would suggest that the presence of the agent had no influence on the observed alterations. In summary, to conclude effectively whether the infectious agent is causing anemia and/or thrombocytopenia in a susceptible dog population, the ratio of these clinical manifestations must be determined in positive and negative animals.

In this study, if only the percentage (28.57\%) of anemic dogs that were positive for $E$. canis was analyzed, the results might suggest that this infectious agent is not an important cause of anemia, since more than $70 \%$ of these cases could have been attributed to anemia of an unknown origin. However, when the proportion of non-reactive dogs was analyzed, it was demonstrated that the 
frequency of anemic dogs is comparatively reduced (13.94\%), which therefore indicates that $\mathrm{CME}$ was responsible for this alteration.

In conclusion, infection induced by $E$. canis is an important cause of anemia and thrombocytopenia in dogs, while $A$. platys cause primarily only thrombocytopenia. Canine monocytic ehrlichiosis and canine thrombocytic anaplasmosis must be included in the differential diagnoses when anemia and/or thrombocytopenia are observed during routine laboratory evaluations.

\section{References}

Aguiar DM, Cavalcante GT, Pinter A, Gennari SM, Camargo LMA, Labruna MB. Prevalence of Ehrlichia canis (Rickettsiales: Anaplasmataceae) in dogs and Rhipicephalus sanguineus (Acari: Ixodidae) ticks from Brazil. J Med Entomol 2007; 44(1): 126-132. http://dx.doi. org/10.1603/0022-2585(2007)44[126:POECRA]2.0.CO;2

Azevedo SS, Aguiar DM, Aquino SF, Orlandelli RC, Fernandes ARF, Uchôa ICP. Soroprevalência e fatores de risco associados à soropositividade para Ehrlichia canis em cães do semiárido da Paraíba. Braz J Vet Res Anim Sci 2011; 48(1): 14-18.

Borin S, Crivelenti LZ, Ferreira FA. Aspectos epidemiológicos, clínicos e hematológicos de 251 cães portadores de mórula de Ehrlichia spp. naturalmente infectados. Arq Bras Med Vet Zootec 2009; 61(3): 566-571. http://dx.doi.org/10.1590/S0102-09352009000300007

Bulla C, Takahira RK, Araújo JP, Trinca LA, Lopes RS, Wiedmeyer CE. The relationship between the degree of thrombocytopenia and infection with Ehrlichia canis in an endemic area. Vet Res 2004; 35(1): 141-146. PMid:15099511. http://dx.doi.org/10.1051/vetres:2003038

Carlos RSA, Carvalho FS, Wenceslau AA, Almosny NRP, Albuquerque GR. Risk factors and clinical disorders of canine ehrlichiosis in the South of Bahia, Brazil. Rev Bras Parasitol Vet 2011; 20(3): 210-214. PMid:21961750. http://dx.doi.org/10.1590/S1984-29612011000300006

Carvalho FS, Wenceslau AA, Carlos RS, Albuquerque GR. Epidemiological and molecular study of Ehrlichia canis in dogs in Bahia, Brazil. Genet Mol Res 2008; 7(3): 657-662. PMid:18752193. http://dx.doi.org/10.4238/ vol7-3gmr468

Cohn LA. Ehrlichiosis and related infections. Vet Clin North Am Small Anim Pract 2003; 33 (4): 863-884. http://dx.doi.org/10.1016/S01955616(03)00031-7

Costa Junior LM, Rembeck K, Ribeiro MFB, Beelitz P, Pfister K, Passos LMF. Sero-prevalence and risk indicators for canine ehrlichiosis in three rural areas of Brazil. Vet J 2007; 174(3): 673-676. PMid:17204439. http://dx.doi.org/10.1016/j.tvjl.2006.11.002

Dagnone AS, Souza AI, André MR, Machado RZ. Molecular diagnosis of Anaplasmataceae organisms in dogs with clinical and microscopical signs of ehrlichiosis. Rev Bras Parasitol Vet 2009; 18(4): 20-25. PMid:20040204. http://dx.doi.org/10.4322/rbpv.01804004

Dagnone AS, Morais HAS, Vidotto MC, Jojima FS, Vidotto O. Ehrlichiosis in anemic, thrombocytopenic, or tick-infested dogs from a hospital population in South Brazil. Vet Parasitol 2003; 117(4): 285-290. PMid:14637030. http://dx.doi.org/10.1016/j.vetpar.2003.10.001

Dagnone AS, Morais HSA, Vidotto O. Erliquiose nos animais e no homem. Semina: Ciênc Agrárias 2001; 22(2): 191-201.
Dantas-Torres F. Canine vector-borne diseases in Brazil. Parasit Vectors 2008; 1(1): 25. PMid:18691408 PMCid:2533296. http://dx.doi. org/10.1186/1756-3305-1-25

De La Fuente J, Torina A, Naranjo V, Nicosia S, Alongi, A La Mantia F, et al. Molecular characterization of Anaplasma platys strains from dogs in Sicily, Italy. BMC Vet Res 2006; 24(2): 5.

Diniz PPVP, Schwartz DS, Morais HAS, Breitschwerdt EB. Surveillance for zoonotic vector-borne infections using sick dogs from southeastern Brazil. Vector Borne Zoonotic Dis 2007; 7(4): 689-697. PMid:18021025. http://dx.doi.org/10.1089/vbz.2007.0129

Dumler JS, Barbet AF, Bekker CPJ, Dasch GA, Palmer GH, Ray $\mathrm{SC}$, et al. Reorganization of genera in the families Rickettsiaceae and Anaplasmataceae in the order Rickettsiales: unification of some species of Ehrlichia with Anaplasma, Cowdria with Ehrlichia and Ehrlichia with Neorickettsia, descriptions of six new species combinations and designation of Ehrlichia equi and "HGE agent" as subjective synonyms of Ehrlichia phagocytophila. Int J Syst Evol Microbiol 2001; 5(6): 2145-2165. http://dx.doi.org/10.1099/00207713-51-6-2145

Faria JLM, Dagnone AS, Munhoz TD, João CF, Pereira WA, Machado RZ, et al. Ehrlichia canis morulae and DNA detection in whole blood and spleen aspiration samples. Rev Bras Parasitol Vet 2010; 19(2): 98-102. PMid:20624346. http://dx.doi.org/10.4322/rbpv.01902006

Felek S, Huang H, Rikihisa, Y. Sequence and Expression Analysis of virB9 of the Type IV Secretion system of Ehrlichia canis strains in ticks, dogs, and cultured cells. Infect Immun 2003; 71(10): 6063-6067. PMid:14500531 PMCid:201090. http://dx.doi.org/10.1128/IAI.71.10.6063-6067.2003

Ferreira RF, Cerqueira AMF, Pereira AM, Guimarães CM, De Sá AG, Abreu FS, et al. Anaplasma platys diagnosis in dogs: comparison between morphological and molecular tests. Intern J Appl Res Vet Med 2007; 5(3): 113-119.

Gaunt SD, Beall MJ, Stillman BA, Lorentzen L, Diniz PPVP, Chandrashekar R, et al. Experimental infection and co-infection of dogs with Anaplasma platys and Ehrlichia canis: hematologic, serologic and molecular findings. Parasit Vectors 2010; 3(1): 33. PMid:20377870 PMCid:2859368. http://dx.doi.org/10.1186/1756-3305-3-33

Gotsch S, Leschnik M, Duscher G, Burgstaller JP, Wille-Piazzai W, Joachim A. Ticks and haemoparasites of dogs from Praia, Cape Verde. Vet Parasitol 2009; 166(1-2): 171-174. PMid:19729247. http://dx.doi. org/10.1016/j.vetpar.2009.08.009

Harrus S, Aroch I, Lavy E, Bark H. Clinical manifestations of infectious canine cyclic thrombocytopenia. Vet Rec 1997; 141(10): 247-250. PMid:9308149. http://dx.doi.org/10.1136/vr.141.10.247

Harvey JW. Trombocytotropic anaplasmosis (A. platys (E. platys) infection). In: Greene CE. Infectious diseases of the dog and cat. $3^{\text {rd }}$ ed. Philadelphia: GREENE; 2006. p. 203-216.

Huang H, Unver A, Perez MJ, Orellana NG, Rikihisa Y. Prevalence and molecular analysis of Anaplasma platys in dogs in Lara, Venezuela. Braz J Microbiol 2005; 36(3): 211-216. http://dx.doi.org/10.1590/S151783822005000300002

Inokuma H, Ohno K, Yamamoto S. Serosurvey of Ehrlichia canis and Hepatozoon canis Infection in Dogs in Yamaguchi Prefecture, Japan. J Vet Med Sci 1999; 6(10): 1153-1155. http://dx.doi.org/10.1292/ jvms.61.1153

Inokuma H, Raoult D, Brouqui P. Detection of Ehrlichia platys DNA in brown dog ticks (Rhipicephalus sanguineus) in Okinawa Island, Japan. J Clin Microbiol 2000; 3(11): 4219-4221. 
Instituto Agronômico do Paraná - IAPAR. Mapas de temperatura [online]. [cited 2011 July. 19]. Available from: http://www.iapar.br/modules/ conteudo/conteudo.php? conteudo $=860$.

Kordick SK, Breitschwerdt EB, Hegarty BC, Southwick KL, Colitz CM, Hancock SI, et al. Coinfection with multiple tick-borne pathogens in a Walker Hound kennel in North Carolina. J Clin Microbiol 1999; 37(8): 2631-2638. PMid:10405413 PMCid:85300.

Macieira DB, Messick JB, Cerqueira AM, Freire IM, Linhares GF, Almeida NK, et al. Prevalence of Ehrlichia canis infection in thrombocytopenic dogs from Rio de Janeiro, Brazil. Vet Clin Pathol 2005; 34(1): 44-48. http://dx.doi.org/10.1111/j.1939-165X.2005.tb00008.x

McBride JW, Corstvet RE, Gaunt SD, Chinsangaram J, Akita GY, Osburn BI. PCR detection of acute Ehrlichia canis infection in dogs. J Vet Diagn Invest 1996; 8(4): 441-447. PMid:8953528. http://dx.doi. org/10.1177/104063879600800406

Moreira SM, Bastos CV, Araújo RB, Santos M, Passos LMF. Retrospective study (1998-2001) on canine ehrlichiosis in Belo Horizonte, Minas Gerais, Brazil. Arq Bras Med Vet Zootec 2003; 55(2): 141-147. http:// dx.doi.org/10.1590/S0102-09352003000200003

Nakaghi ACH, Machado RZ, Costa MT, André MR, Baldani CD. Canine ehrlichiosis: Clinical, hematological, serological and molecular aspects. Ciênc Rural 2008; 38(3): 766-770. http://dx.doi.org/10.1590/ S0103-84782008000300027

Neer TM, Harrus S. Canine monocytotropic ehrlichiosis and neorickettsiosis (E. canis, E. chaffeensis, E. ruminantium, N. sennetsu, and $N$. risticii infections). In: Greene CE. Infectious diseases of the dog and cat. $3^{\text {rd }}$ ed. Philadelphia: GREENE; 2006. p. 203-216.

Ramos CAN, Ramos RAN, Araújo FR, Guedes Junior DS, Souza IIF, Ono TM, et al. Comparação de nested-PCR com o diagnóstico direto na detecção de Ehrlichia canis e Anaplasma platys em cáes. Rev Bras Parasitol Vet 2009; 18(S1): 58-62. PMid:20040193. http://dx.doi.org/10.4322/ rbpv.018e1011

Ramos R, Ramos C, Araújo F, Oliveira R, Souza I, Pimentel D, et al. Molecular survey and genetic characterization of tick-borne pathogens in dogs in metropolitan Recife (north-eastern Brazil). Parasitol Res 2010; 107(5): 1115-1120. PMid:20680344. http://dx.doi. org/10.1007/s00436-010-1979-7

Rodgers SJ, Morton RJ, Baldwin CA. A serological survey of Ehrlichia canis, Ehrlichia equi, Rickettsia rickettsii, and Borrelia burgdorferi in dogs in Oklahoma. J Vet Diagn Invest 1989; 1(2): 154-159. PMid:2518693. http://dx.doi.org/10.1177/104063878900100212

Rodriguez-Vivas RI, Albornoz REF, Bolio GME. Ehrlichia canis in dogs in Yucatan, Mexico: seroprevalence, prevalence of infection and associated factors. Vet Parasitol 2005; 127(1): 75-79. PMid:15619376. http://dx.doi.org/10.1016/j.vetpar.2004.08.022

Saito TB, Cunha-Filho NA, Pacheco RC, Ferreira F, Pappen FG, Farias NA, et al. Canine infection by Rickettsiae and Ehrlichiae in Southern Brazil. Am J Trop Med Hyg 2008; 79(1): 102-108. PMid:18606772.

Santos F, Coppede JS, Pereira AL, Oliveira LP, Roberto PG, Benedetti $\mathrm{RB}$, et al. Molecular evaluation of the incidence of Ehrlichia canis, Anaplasma platys and Babesia spp. in dogs from Ribeirão Preto, Brazil. Vet J2009; 179(1): 145-148. PMid:17920967. http://dx.doi.org/10.1016/j. tvjl.2007.08.017
Silva PFN, Balarin MRS, Maruchi HP, Flaiban KKMC, Moroz LR. Correlação entre o hemocitômetro e outras técnicas de rotina para a contagem do número de plaquetas em cães atendidos no Hospital Veterinário da Universidade Estadual de Londrina (H.V.-UEL). Semina: Ciênc Agrárias 2007; 28(4): 659-664.

Silva JN, Almeida ABPF, Sorte ECB, Freitas AG, Santos LGF, Aguiar DM, et al. Soroprevalência de anticorpos anti Ehrlichia canis em cães de Cuiabá, Mato Grosso. Rev Bras Parasitol Vet 2010; 19(2): 108-111. PMid:20624348. http://dx.doi.org/10.4322/rbpv.01902008

Solano-Gallego L, Hegarty B, Espada Y, Llull J, Breitschwerdt E. Serological and molecular evidence of exposure to arthropod-borne organisms in cats from northeastern Spain. Vet Microbiol 2006; 118(3-4): 274-277. PMid:16919405. http://dx.doi.org/10.1016/j.vetmic.2006.07.010

Souza BM, Leal DC, Barboza DC, Uzêda RS, De Alcântara AC, Ferreira F, et al. Prevalence of ehrlichial infection among dogs and ticks in Northeastern Brazil. Rev Bras Parasitol Vet 2010; 19(2): 89-93. PMid:20624344. http://dx.doi.org/10.4322/rbpv.01902004

Suksawat J, Pitulle C, Arraga-Alvarado C, Madrigal K, Hancock SI, Breitschwerdt EB. Coinfection with three Ehrlichia species in dogs from Thailand and Venezuela with emphasis on consideration of 16 S ribosomal DNA secondary structure. J Clin Microbiol 2001a; 39(1): 90-93. PMid:11136754 PMCid:87685. http://dx.doi.org/10.1128/ JCM.39.1.90-93.2001

Suksawat J, Xuejie Y, Hancock SI, Hegarty BC, Nilkumhang P, Breitschwerdt EB. Serologic and molecular evidence of coinfection with multiple vectorborne pathogens in dogs from Thailand. J Vet Intern Med 2001b; 15(5): 453-462. PMid:11596732. http://dx.doi. org/10.1111/j.1939-1676.2001.tb01574.x

Tamí IDC, Tamí-Maury IM. Identificación morfológica de Ehrlichia sp. en las plaquetas de pacientes con infección por virus de la inmunodeficiencia humana, en Venezuela. Rev Panam Salud Publica 2004; 16(5): 345-349. http://dx.doi.org/10.1590/S1020-49892004001100008

Thrall MA. Tecnologia laboratorial em medicina veterinária. In: Thrall MA. Hematologia e Bioquimica Clínica Veterinária. São Paulo: ROCA; 2007. p. 3-6.

Trapp SM, Dagnone AS, Vidotto O, Freire RL, Amude AM, Morais HSA. Seroepidemiology of canine babesiosis and ehrlichiosis in a hospital population. Vet Parasitol 2006; 140(3-4): 223-230. PMid:16647817. http://dx.doi.org/10.1016/j.vetpar.2006.03.030

Ueno TEH, Aguiar DM, Pacheco RC, Richtzenhain LJ, Ribeiro MG, Paes AC, et al. Ehrlichia canis em cães atendidos em hospital veterinário de Botucatu, Estado de São Paulo, Brasil. Rev Bras Parasitol Vet 2009; 18(3): 57-61. PMid:19772777. http://dx.doi.org/10.4322/ rbpv.01803010

Watanabe M, Okuda M, Tsuji M, Inokuma H. Seroepidemiological study of canine ehrlichial infections in Yamaguchi prefecture and surrounding areas of Japan. Vet Parasitol 2004; 124(1-2): 101-107. PMid:15350665. http://dx.doi.org/10.1016/j.vetpar.2004.07.004

Yabsley MJ, McKibben J, MacPherson CN, Cattan PF, Cherry NA, Hegarty BC, et al. Prevalence of Ehrlichia canis, Anaplasma platys, Babesia canis vogeli, Hepatozoon canis, Bartonella vinsonii berkhoffii, and Rickettsia spp. in dogs from Grenada. Vet Parasitol 2008; 151(2-4): 279-285. PMid:18160223. http://dx.doi.org/10.1016/j.vetpar.2007.11.008 


\section{ERRATA}

Errata do artigo "Occurrence of Ehrlichia canis and Anaplasma platys in household dogs from northern Parana" (http://dx.doi. org/10.1590/S1984-29612012005000009), publicado em ahead of print em 04 de dezembro de 2012. No artigo apresenta erro no nome de um dos autores:

Onde se lê:

Selwyn Headley Arlington

Leia-se:

Selwyn Arlington Headley 